\title{
Penyesuaian Sosial Siswa Akselerasi Ditinjau Dari Konsep Diri dan Membuka Diri
}

\author{
Tri Rejeki Andayani \\ Prodi Psikologi FK UNS, menikpsy@yahoo.com
}

\begin{abstract}
Abstrak: Penelitian ini bertujuan untuk mengetahui hubungan antara konsep diri dan membuka diri dengan penyesuaian sosial siswa akselerasi. Populasi penelitian sebanyak 89 siswa, terdiri atas siswa Akselerasi Kelas X dan XI SMAN 3 Surakarta. Pengumpulan data mengunakan tiga buah skala, yakni : 1) Skala Konsep Diri, validitas item berkisar antara 0,259-0,658, reliabilitas alat ukur 0,848; 2) Skala Membuka Diri, validitas item 0,280-0,694, reliabilitas alat ukur 0,872; dan 3) Skala Penyesuaian Sosial, validitas item 0,284-0,646, reliabilitas alat ukur 0,821. Analisis data menggunakan Teknik Analisis Regresi Ganda. Hasil analisis data menunjukkan bahwa ada hubungan antara konsep diri dan membuka diri dengan penyesuaian sosial siswa akselerasi. Siswa yang memiliki pandangan positif dan menerima diri secara positif akan lebih bersikap terbuka dalam menerima kritik dan memperbaiki diri. Konsep diri yang positif berarti siswa akselerasi memiliki pandangan positif terhadap kemampuan dan keadaan dirinya, sehingga menimbulkan rasa percaya diri untuk membawa dirinya pada lingkungan pergaulan yang lebih luas. Sebaliknya, siswa yang memiliki konsep diri negatif akan mengembangkan perasaan tidak mampu, rendah diri dan cenderung sulit membawa diri pada lingkungan pergaulan yang lebih luas.
\end{abstract}

Kata kunci: konsep diri, membuka diri, penyesuaian diri, dan siswa akselerasi.

\begin{abstract}
The aims of this research is to find out relationship between self-concept and self-disclosure with the social adjustment of them. This study population were 89 students of Class X and XI in the High School (SMAN 3 Surakarta). Collecting data use three scales: 1) Self-concept Scale, the validity of items ranged between $0,259-0,658$, the reliability is $0.848 ; 2$ ) Self-disclosure Scale, the validity of items ranged between 0,280-0,694, reliability is 0.872 ; and 3) Social Adjustment Scale, the validity of the items between $0,284-0,646$, the reliability is 0.821 . Analysis data in this study is using multiple regression analysis technique. The results of multiple regression analysis revealed a significant relationship between selfconcept and self-disclosure with social adjustment of students with acceleration. Student who have a positive self-concept and accept themselves more positively will be open in accepting criticism and inprove ourselves, so that tends to adapt better. Positive self-concept of accelleration means that students have a positive outlook on his ability and circumstances, giving rise to the confidence to bring him to the wider social environtment. However, the student who have negative self-concept will be developed feelings of inadequacy, low self-esteem and tend to carry themselves in difficult social adjustment.
\end{abstract}

Key words: self-concept, self-disclosure, social adjustment, and students with accelerated.

\section{Pendahuluan}

Berdasarkan Undang-Undang Nomor 20, Tahun 2003 Tentang Sistem Pendidikan Nasional (UU Nomor 20/2003), berarti bahwa Sistem Pendidikan Nasional harus mampu menjamin pemerataan kesempatan pendidikan, peningkatan mutu, relevansi dan efisiensi pengelolaan manajemen pendidikan. Hal ini dimaksudkan untuk menghadapi tantangan sesuai tuntutan perubahan kehidupan lokal, nasional, dan global. Salah satu program yang diselenggarakan oleh Direktorat Pembinaan Sekolah Luar Biasa adalah Program Percepatan Belajar (Akselerasi). Program ini merupakan salah satu upaya strategis yang dilakukan untuk memberikan layanan pendidikan yang terbaik bagi anak-anak berkebutuhan khusus, berkecerdasan istimewa, dan keberbakatan istimewa di Indonesia.

Penyelenggaraan program percepatan belajar (akselerasi) telah dilaksanakan di sekolah dasar 
(SD), sekolah menengah pertama (SMP), dan sekolah menengah atas (SMA). Kelas akselerasi ini diadakan oleh Departemen Pendidikan Nasional yang diatur dalam UU 20/2003, sebagai usaha memenuhi kebutuhan belajar siswa yang memiliki kapasitas intelektual tinggi (gifted) atau yang berada dalam kategori siswa cepat (fast learners).

Implementasi pelayanan pendidikan bagi peserta didik yang memiliki potensi kecerdasan dan bakat istimewa diatur dengan Kepmedikbud Nomor 0487/U/1992 untuk tingkat Sekolah Menengah Atas (SMA) ditindaklanjuti dengan Pasal 16, Ayat (1) menyatakan bahwa "Siswa yang memiliki bakat istimewa dan kecerdasan luar biasa dapat menyelesaikan program belajar lebih awal dari waktu yang telah ditentukan, dengan ketentuan-ketentuan mengikuti di SMU sekurangkurangnya dua tahun"; Ayat (2) "Pelaksanaan ketentuan sebagaimana dimaksud dalam ayat (1) ditetapkan oleh Direktur Jenderal".

Siswa tingkat SMA merupakan kelompok remaja yang memiliki tugas perkembangan yang berhubungan dengan perkembangan sosial emosional. Dikatakan Hurlock (1997:213) bahwa salah satu tugas perkembangan masa remaja yang tersulit adalah penyesuaian sosial. Dikatakan lebih lanjut bahwa penyesuaian sosial adalah kemampuan seseorang dalam menyesuaikan diri dengan orang lain pada umumnya dan kelompok pada khususnya.

Sebagai salah satu SMA yang berprestasi di Surakarta, maka SMAN 3 Surakarta ditunjuk sebagai penyelenggara program akselerasi tersebut sejak tahun 2005. Sebagaimana diketahui, bahwa salah satu persyaratan dasar bagi siswa peserta program akselerasi adalah siswa dengan Intelligence Quotient (IQ) diatas 125 atau menunjukkan prestasi akademik yang menonjol. Peserta didik akselerasi dituntut untuk menguasai materi pelajaran yang telah dipadatkan dari kurun waktu belajar selama tiga tahun menjadi dua tahun saja.

Pemadatan materi akademik tersebut membawa berbagai konsekuensi, baik segi positif maupun negatif. Salah satu segi positif yang menonjol adalah terpenuhinya kebutuhan belajar peserta didik, khususnya siswa cerdas istimewa bakai istimewa sesuai dengan karakteristik keunggulan dan kebutuhan masing-masing siswa dalam rentang waktu yang lebih singkat, sehingga ada efisiensi dan efektifitas proses pendidikan. Namun demikian terdapat satu hal lain yang harus dicermati dari sisi negatifnya, yakni semakin berkurangnya waktu untuk pengembangan diri siswa dari segi sosial emosional, sebab dengan pemadatan dan percepatan materi tersebut maka peserta didik cenderung dituntut memacu aspek kognitif saja.

Hasil-hasil riset menunjukkan bahwa anak yang memiliki potensi kecerdasan dan bakat istimewa sering mengalami kesulitan untuk mengenali diri dan mengembangkan dirinya secara optimal, mengalami kesulitan dalam menjalin relasi dengan orang lain, serta mengalami kesulitan dalam mengelola emosinya sehingga prestasi belajarnya cenderung tidak optimal bila dibandingkan dengan potensi yang dimiliki (underachiever) atau bahkan mengalami kesulitan belajar.

Hasil penelitian yang dilakukan oleh Universitas Nijmegen Belanda menunjukkan setengah dari populasi anak-anak berbakat mengalami prestasi rendah dan tidak sesuai dengan potensi yang dimilikinya. Hal itu disebabkan karena dukungan terhadap perkembangan dan intelektualnya di rumah, sekolah dan masyarakat kurang memadai.

Hasil penelitian Iswinarti (2002:71) mengungkapkan bahwa beberapa anak dengan IQ tinggi mengalami kesulitan penyesuaian sosial, karena kemampuan siswa yang menonjol tersebut pada akhirnya tidak sepadan dengan rata-rata teman sebaya. Perbedaan yang cukup menonjol tersebut seringkali menjadi tekanan bagi siswa yang bersangkutan, apalagi bila lingkungan lalu memberikan labelling tertentu. Akibatnya, ada kecenderungan untuk memperlakukan siswa sesuai dengan label yang diberikan. Pandangan dan penilaian tersebut akan mempengaruhi cara pandang siswa terhadap dirinya sendiri dan pada akhirnya mempengaruhi konsep dirinya. Konsep diri inilah yang akan mempengaruhi cara individu berinteraksi dengan lingkungannya (Burns, 1993:19; Rakhmat, 2000:104).

Pada sisi lain, salah satu cara mengurangi perasaan dan pikiran yang "terbebani" tuntutantuntutan tersebut adalah dengan jalan membuka diri pada orang lain, baik pada teman sebaya atau 
orang tua dan guru. DeVito (1989:125) mengatakan bahwa remaja akan lebih banyak membuka diri pada teman-teman sebayanya daripada orang tua. Demikian pula yang terjadi pada peserta didik akselerasi, ada kecenderungan peserta didik untuk lebih terbuka pada teman-temannya daripada orang tua yang biasanya menuntut keberhasilan secara terus menerus pada anaknya. Tuntutan dan harapan yang tinggi tersebut seringkali menjadi beban bagi siswa yang bersangkutan. Pada akhirnya justru mengurangi kemungkinan siswa untuk membuka diri dengan orang tuanya.

Dari penjelasan tersebut di atas dapat dirumuskan permasalahan sebagai berikut apakah ada hubungan antara konsep diri dan membuka diri dengan penyesuaian sosial siswa akselerasi? Adapun tujuan penelitian ini untuk mengetahui adanya hubungan antara konsep diri dan membuka diri dengan penyesuaian sosial siswa akselerasi.

\section{Kajian Literatur}

Akselerasi atau yang disebut juga dengan telescoping curriculum content merupakan peluang bagi siswa untuk belajar sesuai dengan kecepatan kemampuan kognitifnya. Presscy (Hawadi, 2004) mendefinisikan akselerasi sebagai suatu kemajuan yang diperoleh pada suatu program pengajaran dalam waktu yang lebih cepat atau usia yang lebih muda daripada waktu yang konvensional. Definisi tersebut mengandung pengertian bahwa siswa mendapat kesempatan untuk memperoleh materi secara lebih cepat dibandingkan kemajuan rata-rata siswa lain. Sebagaimana yang dikemukakan oleh Semiawan (1997) bahwa akselerasi adalah peningkatan kecepatan waktu siswa dalam menguasai materi.

Penyelenggaraan Program Percepatan Belajar (Akselerasi) merupakan salah satu program untuk memenuhi kebutuhan belajar anak cerdas, berbakat dan istimewa (Kemendiknas Nomor 0488/U/1992). Definisi peserta didik yang memiliki potensi kecerdasan dan bakat istimewa dalam Program Percepatan Belajar adalah mereka yang oleh psikolog dan/atau guru diidentifikasi sebagai peserta didik yang telah mencapai prestasi memuaskan dan memiliki kemampuan intelektual umum yang berfungsi pada taraf cerdas, kreativitas yang memadai, dan keterikatan terhadap tugas yang tergolong baik.
Kelas akselerasi memiliki dua tujuan, yakni tujuan umum dan tujuan khusus (Hawadi, 2004). Tujuan umum yang ingin dicapai adalah memberikan pelayanan terhadap siswa yang memiliki karakteristik khusus pada aspek kognitif dan aspek afeksinya. Selain itu, untuk memenuhi minat inteletual dan perspektif masa depan siswa, termasuk menyiapkan siswa menjadi seorang pemimpin. Tujuan khusus adalah menghargai siswa yang memiliki kemampuan dan kecerdasan luar biasa agar dapat menyelesaikan pendidikan lebih cepat, memacu kualitas dalam meningkatkan kecerdasan spiritual, intelektual, dan emosional secara seimbang, meningkatkan efisiensi dan efektivitas proses belajar mengajar kelas akselerasi.

Pada umumnya gambaran ciri-ciri atau karakteristik anak berbakat menimbulkan kesan seolah-olah anak yang berpotensi kecerdasan dan bakat istimewa hanya memiliki sifat-sifat positif. Padahal kebutuhan psikologis mereka sebagai anak tetaplah sama dibandingkan anakanak lain seusianya. Kebutuhan psikologis yang kurang terpenuhi mengakibatkan anak mengalami kesulitan dalam beradaptasi terhadap tuntutan tugas perkembangan maupun terhadap tuntutan lingkungan sosial yang dihadapi sehingga anak mengalami kesulitan dalam mengembangkan potensi kecerdasan dan bakat istimewa yang dimiliki secara optimal.

Penyesuaian sosial merupakan salah satu hal terpenting pada usia remaja, karena keberhasilan seseorang dalam proses penyesuaian ini akan menjadi landasan kuat untuk meraih keberhasilan pada tugas perkembangan selanjutnya. Penyesuaian sosial adalah keberhasilan individu dalam menyesuaikan diri dengan orang lain pada umumnya atau kelompok pada khususnya, definisi tersebut dinyatakan oleh Hurlock (1997:287). Lebih lanjut dikatakannya bahwa terdapat empat aspek dalam penyesuaian sosial, yakni: 1) perilaku yang ditampilkan; 2) penyesuaian diri terhadap berbagai kelompok; 3) sikap sosial; dan 4) kepuasan pribadi. Pengertian lain diungkapkan oleh Scheniders (1964:183) bahwa penyesuaian sosial adalah kemampuan individu untuk bereaksi secara sehat dan efektif terhadap hubungan, situasi dan realitas sosial sehingga tercapai kehidupan yang menyenangkan dan memuaskan. 
Disebutkannya terdapat tiga aspek dalam penyesuaian sosial, meliputi: 1) penyesuaian di rumah atau lingkungan keluarga; 2) penyesuaian di sekolah; dan 3) penyesuaian di masyarakat. Tampak bahwa aspek dalam pandangan Scheniders disusun berdasarkan lingkungan sosial yang diterkait dengan kehidupan sehari-hari remaja dalam memerankan dirinya dan menjalankan tugas perkembangan tersebut.

Kemampuan remaja dalam menyesuaikan diri di berbagai lingkungan sosial tersebut dipengaruhi oleh berbagai faktor. Di antaranya pola asuh orang tua, teman sebaya, penerimaan diri, pendidikan masa kanak-kanak, wawasan sosial dan jenis kelamin (Hurlock, 1997:258). Beberapa faktor tersebut dilengkapi oleh Scheniders (1964:122-133) bahwa kondisi fisik dan determinannya, perkembangan dan kematangan individu, determinan psikologis, kondisi lingkungan dan determinan budaya dan agama turut mempengaruhi proses penyesuaian sosial seseorang.

Dari faktor-faktor tersebut, diungkapkan peran konsep diri sebagai bagian dari faktor penerimaan diri dan kondisi fisik serta peran kemampuan membuka diri dalam proses penyesuaian sosial remaja, khususnya siswa akselerasi. Sebagaimana diketahui, bahwa siswa akselerasi adalah individu yang mengikuti program percepatan belajar, sehingga dituntut untuk lebih berprestasi dan mampu menguasai materi akademik lebih cepat dari teman sebayanya yang kebetulan tidak memiliki tingkat kecerdasan setinggi dirinya. Tuntutan dan harapan yang tinggi dari lingkungan menciptakan pandangan dan penilaian tertentu pada siswa akselerasi tersebut dan pada akhirnya mempengaruhi konsep dirinya.

Konsep diri adalah perasaan, pandangan dan penilaian individu mengenai dirinya yang diperoleh dari hasil interaksi dengan lingkungannya (Mead dalam Burns, 1993:9). Dikatakan oleh Hurlock (1999:237) bahwa konsep diri adalah pandangan individu mengenai dirinya (konsep diri sebenarnya) dan gambaran individu mengenai diri yang diinginkannya (konsep diri ideal). Menurutnya terdapat dua aspek dalam konsep diri, yakni aspek fisik dan aspek psikologis.

Kajian penelitian ini mencermati adanya peran konsep diri dan membuka diri dalam proses penyesuaian sosial remaja, khususnya siswa akselerasi. Sedikitnya, kesempatan siswa akselerasi untuk mengembangkan aspek sosial emosional karena padatnya kegiatan belajar dan mengerjakan tugas-tugas akademik dapat menurunkan kemampuan penyesuaian sosialnya. Ditambah dengan munculnya label/cap sebagai anak pintar, sempurna dan dituntut selalu berprestasi kadangkala justru membawa konsekuensi negatif karena beban berat. Terlebihlebih bila siswa tersebut tidak mampu memenuhi harapan dan tuntutan tersebut, sehingga akan muncul perasaan gagal dan frustasi yang dapat menimbulkan penilaian terhadap dirinya secara negatif. Pandangan atau gambaran mengenai dirinya tersebut terkait dengan proses pembentukan konsep diri seseorang, yang pada akhirnya mempengaruhi cara seseorang membawa dirinya dalam lingkungan sosialnya (Tjahjono, 2002:83).

Saat berinteraksi sosial, muncul proses komunikasi yang ditandai dengan adanya pertukaran informasi. Salah satu faktor yang menentukan komunikasi tersebut adalah kemampuan seseorang dalam mengungkapkan perasaan, pandangan dan pengalamannya yang relevan untuk memahami situasi baru (Jourard dalam Brems dkk, 1992:189). Menurut Sears, dkk (1992:254) terdapat dua tipe dalam membuka diri yakni secara deskriptif dan evaluatif. Secara deskriptif, membuka diri mengenai fakta tentang identitas pribadi, misalnya nama, tempat tinggal, pekerjaan dan lain sebagainya. Secara evaluatif membuka diri meliputi pengungkapan perasaan, opini dan penilaian diri mengenai sesuatu hal yang bisa jadi berbeda dengan lawan bicaranya.

Berbagai penelitian mengungkapkan bahwa remaja pada umumnya memiliki kebutuhan untuk membuka diri, di mana penyaluran kebutuhan ini sangat dipengaruhi oleh tingkat kepercayaan (Supratiknya, 1995:28). Seperti diketahui bahwa usia remaja memiliki kecenderungan untuk lebih percaya pada teman sebaya katimbang pada orang tua. Kepercayaan dalam hubungan pertemanan remaja terkait dengan keyakinan remaja terhadap orang terdekatnya akan secara sukarela merespon kebutuhannya atau bersedia mengalah terhadap keinginannya sendiri (Rempel dkk, 2001:58). Diharapkan dengan keterampilan 
membuka diri dalam komunikasi inilah maka remaja akan lebih mudah dalam melakukan penyesuaian sosial, baik di lingkungan keluarga, sekolah maupun masyarakat.

Berdasarkan hal tersebut di atas, maka hipotesis yang diajukan dalam penelitian ini adalah ada hubungan antara konsep diri dan membuka diri dengan penyesuaian sosial siswa akselerasi.

\section{Metodologi Penelitian}

Variabel dalam penelitian ini meliputi variabel kriterium (penyesuaian sosial) dan variabel prediktor (konsep diri dan membuka diri). Penyesuaian sosial adalah kemampuan seseorang untuk bereaksi secara tepat terhadap suatu hubungan, situasi dan realitas sosial sehingga mencapai kehidupan sosial yang lebih menyenangkan dan memuaskan. Konsep diri adalah gambaran dan penilaian seseorang mengenai dirinya, baik dari aspek fisik maupun aspek psikologis. Membuka diri adalah kemampu-an seseorang untuk mengungkapkan berbagai informasi, tanggapan, perasaan, permasalahan dan mengekspresikan emosi terhadap orang lain.

Populasi penelitian ini adalah Siswa Akselerasi Kelas X dan XI SMAN 3 Surakarta, dan penelitian ini merupakan studi populasi dengan jumlah populasi sebanyak 89 orang. Penelitian dilakukan pada saat pelaksanaan Program Pendampingan Psikologis Siswa Akselerasi SMAN 3 Surakarta pada Tahun Akademik 2007/2008. Pengumpulan data menggunakan tiga buah skala, yakni: 1) Skala Konsep Diri, validitas item berkisar antara 0,2590,658 , reliabilitas alat ukur 0,$848 ; 2$ ) Skala Membuka Diri, validitas item 0,280-0,694, reliabilitas sebesar 0,872; dan 3) Skala Penyesuaian Sosial, validitas item 0,284-0,646, reliabilitas alat ukur 0,821.

Analisis data dalam penelitian ini menggunakan teknik analisis regresi ganda.

\section{Hasil Penelitian dan Bahasan}

Dari hasil analisis data membuktikan ada hubungan positif antara konsep diri dan membuka diri dengan penyesuaian sosial siswa akselerasi, dengan Koefisien Korelasi sebesar 0,473 ( $p: 0,000$; $\mathrm{p}<0,05)$. Pengujian hipotesis ini menjadi salah satu bukti bahwa siswa yang memiliki pandangan positif dan menerima diri secara positif akan lebih bersikap terbuka dalam menerima kritik dan memperbaiki diri, sehingga cenderung dapat menyesuaikan diri dengan lebih baik. Konsep diri yang positif berarti siswa akselerasi memiliki pandangan positif terhadap kemampuan dan keadaan dirinya, sehingga menimbulkan rasa percaya diri untuk membawa dirinya pada lingkungan pergaulan yang lebih luas. Antusiasme dalam menjalin relasi inilah yang mendukung keberhasilan penyesuaian diri siswa akselerasi. Sebaliknya, bila siswa akselerasi memiliki konsep diri negatif maka akan mengembangkan perasaan tidak mampu, rendah diri dan cenderung sulit membawa diri pada lingkungan pergaulan yang lebih luas.

Hasil penelitian ini sejalan dengan penelitian sebelum yang dilakukan oleh Ary, Andayani dan Sawitri (2005) pada Siswa Akselerasi SMPN 2 Semarang dan SMP Pangudi Luhur Domenico Savio Semarang. Pada penelitian tersebut juga menunjukkan adanya korelasi yang signifikan antara konsep diri dan penyesuaian diri pada siswa akselerasi. Demikian pula penelitian dari Agustiani (2002) yang membuktikan bahwa remaja dengan gambaran diri positif cenderung lebih mudah menyesuaikan diri dengan lingkungannya, serta penelitian dari Hartanti dan Dwijanti (1997) yang menunjukkan bahwa pandangan individu terhadap dirinya memiliki pengaruh pada seberapa besar individu memberi peluang pada dirinya untuk berkembang dan melakukan penyesuaian sosial. Peserta didik yang memiliki konsep diri dan gambaran diri secara positif serta didukung dengan kemampuan untuk membuka diri, menyampaikan pendapat dan ideidenya akan lebih mudah menyesuaikan diri dengan lingkungan sosialnya, termasuk menyesuaikan tugas-tugas dan tuntutan akademik di sekolah. Pada umumnya, peserta didik akselerasi pada SMAN 3 Surakarta rata-rata pada kategori tinggi, sehingga dengan konsep diri yang positif tersebut menjadi modal untuk melakukan penyesuaian sosial secara lebih mudah.

Dapat dikatakan bahwa salah satu faktor yang menunjang keberhasilan penyesuaian sosial siswa akselerasi adalah keterampilan dalam berkomunikasi, termasuk di dalamnya kemampuan untuk membuka diri dengan orang lain. Sebagaimana diketahui bahwa kebanyakan siswa kelas 
akselerasi tidak memiliki kesempatan luas untuk belajar mengembangkan aspek afektif dan aspek sosial. Hal itu disebabkan karena padatnya materi yang harus mereka terima, banyaknya pekerjaan rumah yang harus mereka selesaikan, ditunjang kemampuan intelektual yang mereka miliki dan teman-teman sekelas yang rata-rata pandai, membuat iklim kerja sama mereka menjadi terbatas. Oleh karena itu, untuk mendukung pengembangan diri yang selaras dengan percepatan kapasitas intelektualnya, maka diperlukan pendampingan psikologis, menyangkut pengembangan aspek kecerdasan emosi, kemampuan sosialisasi dan komunikasi di antara mereka. Pada Siswa Akselerasi SMAN 3 Surakarta telah diberikan pelatihan pengembangan diri khususnya terkait dengan peningkatan keterampilan komunikasi, khususnya kemampuan membuka diri. Pelatihan tersebut bertujuan untuk mengembangkan aspek kerja sama dan aspek sosial dari siswa akselerasi (Andayani, 2007). Dari pengukuran mengenai kemampuan membuka dirinya, menunjukkan bahwa Siswa Akselerasi SMAN 3 Surakarta berada pada kategori tinggi. Dengan demikian diharapkan seiring dengan meningkatnya keterampilan komunikasi mereka, khususnya keberanian untuk membuka diri akan menunjang kesuksesan penyesuaian sosialnya.

Terkait dengan proses pendidikan, maka penyesuaian sosial setiap siswa meliputi penyesuaian sosial di rumah, di sekolah dan di masyarakat. Sebagaimana yang dikemukakan oleh Ki Hajar Dewantara tentang adanya tiga lingkungan pendidikan bagi anak, yakni keluarga, sekolah, dan masyarakat atau yang disebut dengan Tri Pusat Pendidikan. Keluarga, sebagai lingkungan yang paling dekat dengan kehidupan anak memiliki arti penting pertumbuhan dan perkembangan siswa akselerasi. Jika pendidikan di sekolah dibangun atas dasar tatanan yang diformalkan dan pertimbangan rasional maka pendidikan anak dalam keluarga didasarkan pada adanya ikatan emosional antara orang tua dan anak. Pembentukan konsep diri yang positif dan keberanian membuka diri dimulai dari lingkungan yang kondusif dalam keluarga. Pengalaman sosial awal dalam keluarga yang berupa penerimaan orang tua dan pola pengasuhan akan membentuk konsep diri anak. Kebanyakan siswa akselerasi merupakan individu yang berasal dari orang tua/ generasi yang lebih terbuka dan mengembangkan pola asuh demokratis. Dikatakan Santrock (1995) bahwa pengasuhan demokratis oleh orangtua akan membuat anak lebih kompeten, percaya diri dan bertanggung jawab secara sosial.

Ketimpangan pendidikan formal di sekolah yang mengedepankan pemenuhan aspek kognitif dan kurang mengembangkan aspek emosi dan spiritual siswa hendaknya dipenuhi melalui pendidikan informal dalam keluarga, terutama oleh orang tua. Individu atau siswa belajar menjalin relasi harmonis dengan anggota keluarga lain, bertanggung jawab menerima tugasnya, menerima otoritas orang tua, serta saling bekerja sama dengan anggota keluarga lainnya. Bila siswa akselerasi mampu mengembangkan sikap dan perilaku sosial yang positif di rumah, maka hal ini akan menjadi bekal untuk mengembangkan keterampilan sosialnya di lingkungan sekolah dan masyarakat.

Sekolah, merupakan lembaga pendidikan formal yang dikelola secara terstruktur dengan melibatkan berbagai komponen, yakni manajemen, kurikulum, siswa, guru, sarana dan prasarana. Sebagai sistem sosial, sekolah merupakan organisasi yang interaktif dan dinamis karena didalamnya terdapat individu-individu yang memiliki potensi dan latar belakang berbeda-beda. Siswa akselerasi mulai memahami bahwa guru dan siswa lainnya, baik dari program yang sama maupun program reguler merupakan partner dalam penyesuaian sosial. Dengan memberikan peluang untuk bekerja sama dan berinteraksi secara luas di luar komunitas akselerasinya maka siswa tidak akan merasa eksklusif. Keluasan pergaulan dan kesempatan inilah yang dibangun di lingkungan pendidikan SMAN 3 Surakarta.

Sebagai mahluk sosial, setiap individu tidak terlepas dari interaksi dengan anggota masyarakat lainnya. Selain dari keluarga dan di sekolah, siswa akselerasi juga belajar dari lingkungan masyarakatnya, mereka mempelajari sesuatu melalui apa saja yang sedang berlangsung di sekitarnya. Semakin lama dan semakin banyak pengalaman -keberhasilan ataupun kegagalan maka kemampuannya untuk menyelesaikan sejumlah persoalan dalam hidup semakin terasah. Dengan kata lain, lingkungan masyarakat 
merupakan tempat mendidik dan mendewasakan siswa dan keberhasilan pendidikan dalam lingkungan masyarakat melibatkan dua faktor penting, yakni potensi siswa dalam memilih lingkungan pergaulan dan nilai yang berkembang di masyarakat.

Oleh karena itu, pendidikan yang mengembangkan aspek kognitif, afektif dan sosial perlu dilakukan baik dalam lingkungan keluarga, sekolah dan masyarakat agar setiap siswa cerdas berbakat dan istimewa memiliki peluang dan kesempatan yang luas untuk mengoptimalkan potensinya.

\section{Simpulan dan Saran}

\section{Simpulan}

Dari penelitian ini dapat disimpulkan bahwa terdapat hubungan positif antara konsep diri dan membuka diri dengan penyesuaian sosial siswa akselerasi.

\section{Saran}

Berdasarkan simpulan tersebut, saran bagi para siswa, sekolah dan keluarga meman-faatkan waktu luang untuk beraktivitas yang dapat mendukung pengembangan keterampilan sosial siswa akselerasi. Bagi peneliti selanjutnya yang menaruh perhatian sama pada program pendidikan akselerasi untuk mengembangkan penelitian lain yang mengungkap aspek-aspek psikologis lain dari pengembangan pribadi siswa akselerasi.

\section{Pustaka Acuan}

Agustiani, H. 2002. Perkembangan Remaja Menurut Pendekatan Ekologi serta Hubungannya dengan Konsep Diri dan Penyesuaian Diri Remaja. Jurnal Psikologi UNPAD. Vol 9 (1) hal 13-29. Bandung: Universitas Padjajaran.

Andayani, T.R. 2007. Program Pendampingan Psikologis, Pengembangan Ketrampilan sosial dan Pengelolaan Emosi Siswa Akselerasi SMAN 3 Surakarta (Laporan Kegiatan). Semarang: Fakultas Psikologi Undip.

Burns,R.B. 1993. Konsep Diri: Teori, Pengukuran, Perkembangan dan Perilaku (Alih bahasa : Eddy). Jakarta: Arcan.

Brems, C; Fromme, D.K; Johnson, M.E. 1992. Group Modification of Emphatic Verbalizations and SelfDisclosure. Journal of Personality and Social Psychology. Vol. 132 (2), p.189-200. APA inc.

DeVito, Joseph. 1989. The Interpersonal Communication Book $\left(5^{\text {th }}\right)$. New York: Hunter Colledge of The City, University of NY.

Hartanti dan Dwijanti, J. 1997. Hubungan antara Konsep Diri dan Kecemasan Menghadapi Masa Depan dengan Penyesuaian Sosial Anak-anak Madura. Anima-Indonesian Psychological Journal. Vol 12 (46), h.145-161. Surabaya: UNAIR.

Hawadi, R.A. 2004. Akselerasi (A-Z Informasi Program Percepatan dan Anak Berbakat Intelektual). Jakarta: Gramedia.

Hurlock, E.B. 1997. Psikologi Perkembangan : Suatu Pendekatan Sepanjang Rentang Kehidupan (Alih bahasa: Istiwiayati \& Soedjarwo). Jakarta : Erlangga.

Hurlock. E.B. 1999. Perkembangan Anak (Jilid II). Alih bahasa : Tjandrasa \& Zarkasih. Jakarta : Erlangga.

Iswinarti. 2002. Penyesuaian Sosial Anak Gifted. Anima-Indonesian Psychological Journal. Vol 18 (1), h.71-79. Surabaya: UNAIR.

Keputusan Menteri Pendidikan dan Kebudayaan Nomor 0487/U/1992 Tentang Percepatan Belajar (Akselerasi). 
Keputusan Menteri Pendidikan dan Kebudayaan Nomor 0488/U/1992 Tentang Percepatan Belajar (Akselerasi).

Rakhmat, J. 2000. Psikologi Komunikasi. Bandung : Rosdakarya.

Rempel, J.K; Ross, M; Holmes,J.G. 2001. Trust and Communicated Attributions in Close Relationships. Journal of Personality and Social Psychology. Vol 81 (1), p.57-64. APA Inc.

Santrock, J. W. 1995. Life Span Development (Jilid I). Alih Bahasa : Chaisari dan Damanik. Jakarta: Erlangga.

Scheniders, A.A. 1964. Personal Adjusment and Mental Health. New York: Holt Rinehart \& Winston.

Sears, D.O; Freedman, J.L; Peplau, L.A. 1992. Psikologi Sosial (Jilid I). Alih bahasa: Michael Adryanto. Jakarta : Erlangga.

Semiawan, C. 1997. Perspektif Pendidikan Anak Berbakat. Jakarta: Gramedia.

Supratiknya, A. 1995. Komunikasi Antar Pribadi: Tinjauan Psikologis. Yogyakarta: Kanisius.

Tjahjono, E. 2002. Mengapa Aku Berbakat? Pandangan Anak Berbakat tentang Dirinya. AnimaIndonesian Psychological Journal. Vol. 80 (1), h.80-90. Surabaya: UNAIR.

Undang-Undang Republik Indonesia Nomor 20, Tahun 2003 Tentang Sistem Pendidikan Nasional. 